\title{
Stage IC Ovarian Cancer AJCC v8
}

National Cancer Institute

\section{Source}

National Cancer Institute. Stage IC Ovarian Cancer A/CC v8. NCI Thesaurus. Code C139967.

Stage IC includes: T1c, N0, M0. T1c: Ovarian cancer with tumor limited to one or both ovaries, with any of the following: surgical spill, capsule ruptured before surgery or tumor on ovarian surface, or malignant cells in ascites or peritoneal washings. N0: No regional lymph node metastasis. M0: No distant metastasis. (AJCC 8th Ed.) 